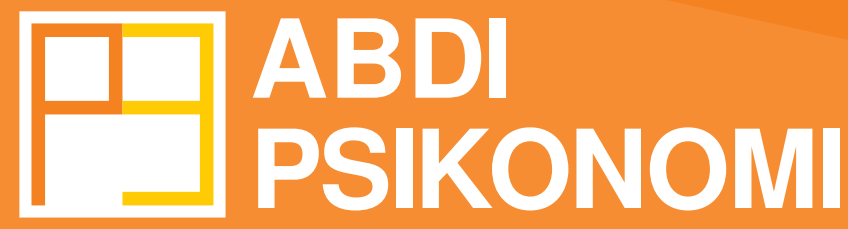

Volume 2, Nomor 2, Desember 2021

http://journals.ums.ac.id/indeksphp/abdipsikonomi

\title{
PENDAMPINGAN PENINGKATAN KEMAMPUAN TAHSIN TAHFIDZ MELALUI PROGRAM PEMBERANTASAN BUTA HURUF AL QUR'AN DI KOMUNITAS EXS PREMAN SOLO
}

Nurul Latifatul Inayati, S.Pd.I., M.Pd.I, Diyah Purnamasari, Ahmad Imam Utomo

Universitas Muhammadiyah Surakarta

Email: n1122@ums.ac.id, ahmadimamutomo@gmail.com, diyahsari733@gmail.com

\section{ABSTRAK}

Komunitas hijrah yang diberi nama komunitas Exspreso atau Exs Preman Solo berdiri pada juli tahun 2016 sebagai wadah dengan anggota yang dulunya preman, anak jalanan, pengedar maupun pemakai obat terlarang yang pada akhirnya mereka telah menentukan pilihan hidup untuk kembali kepada jalan yang lurus yang diridhoi Allah Subhanahu Wa Ta'ala. Komunitas ini mengupayakan dan memfasilitasi setiap anggotanya belajar melalui program pemberantasan buta huruf al Qur'an untuk meningkatkan kemampuan tahsin tahfidz sehingga diharapkan tidak salah langkah dalam mempelajari serta mengamalkan $\mathrm{Al}$ Qur'an. Minimnya pembina dalam hal ini asatid dan banyaknya anggota yang membutuhkan pendampingan sehingga pengurus yang masih kurang dalam segi kemampuan akan menjadi penyebab kurang maksimalnya upaya peningkatan kemampuan tahsin tahfidz, maka diperlukan pendampingan dengan harapan mampu meningkatkan kemampuan para pengurus dalam peningkatan kemampuan yang dilakukan terhadap anggota, dan dengan harapan kegiatan ini dapat terlaksana secara berkelanjutan agar tercapai tujuan yang diharapkan.

Kata Kunci: Pendampingan, peningkatan tahsin tahfidz, komunitas exs preman Solo. 


\section{Pendahuluan}

Komunitas hijrah yang diberi nama komunitas Exspreso atau Exs Preman Solo ini, didirikan oleh Ustadz Suyudi Nugroho terletak di Jl. Surya No. 145 Jagalan, Kec. Jebres, Kota Surakarta, komunitas ini berdiri pada juli tahun 2016 sebagai wadah dengan anggota yang dulunya preman, anak jalanan, pengedar maupun pemakai obat terlarang yang pada akhirnya mereka telah menentukan pilihan hidup untuk kembali kepada jalan yang lurus yang diridhoi Allah Subhanahu Wa Táala. Terdapat beberapa program yang salah satunya mengarah pada pendampingan peningkatan kemampuan tahsin tahfidz, dan pelaksanaan pendampingan pada komunitas ini diwujudkan melalui program tersebut.

Komunitas ini mengupayakan dan memfasilitasi setiap anggotanya belajar melalui program pemberantasan buta huruf al Qur'an sehingga diharapkan tidak salah langkah dalam mempelajari serta mengamalkan $\mathrm{Al}$ Qur'an yang menjadi pedoman hidup umat Islam. Minimnya pembina dalam hal ini asatid dan banyaknya anggota yang membutuhkan pendampingan sehingga pengurus yang masih kurang dalam segi kemampuan diharuskan mampu membantu dalam pelaksanaan pembinaan. Hal tersebut mengkhawatirkan jika berlangsung lebih lama lagi, akan menjadi penyebab kurang maksimalnya upaya peningkatan kemampuan tahsin tahfidz.

Melihat permasalahan yang ada, penulis ingin membantu para pengurus komunitas untuk lebih maksimal lagi dalam melakukan pendampingan terhadap para anggota dengan sama-sama belajar sehingga diharapkan terdapat perubahan agar mampu membantu pelaksanaan pendampingan.

Tujuan dari pendampingan ini ialah mampu meningkatnya kemampuan para pengurus komunitas dalam peningkatan kemampuan tahsin tahfidz sehingga kedepannya diharapkan mampu menjalankan pendampingan dengan lebih baik lagi sesuai yamg dirapkan.

Pengabdian ini akan dilaksanakan dengan pendampingan, bimbingan, pengarahan, serta saran dan masukan. Dengan ini, kami Fakultas Agama Islam jurusan Pendidikan Agama Islam Universitas Muhammadiyah Surakarta akan melaksanakan kegiatan dengan tema "Pendampingan Peningkatan Kemampuan Tahsin Tahfidz melalui Program Pemberantasan Buta Huruf Al Qur'an di Komunitas Exs Preman Solo".

\section{Metode}

Metode yang digunakan pada kegiatan ini, antara lain:

a. Melakukan pendampingan terhadap pengurus

Dilakukan dengan cara melakukan pendampingan pengurus dalam melaksanakan program yang telah rutin berjalan sebelumnya.

b. Melakukan bimbingan dan mengarahkan pengurus

Dilakukan dengan cara memberi bimbingan dalam pelaksanaan program seperti, memberi contoh pelaksanaan dengan metode efektif dan inovatif.

c. Memberi masukan dan saran terhadap pengurus

Dilakukan dengan cara memberi saran atau masukan terhadap keseluruhan program yang telah dilaksanakan, ketika dirasa masih perlu dilakukan perbaikan terhadap masalah yang muncul saat pembinaan.

\section{Hasil dan Pembahasan}

Kegiatan pendampingan ini dilaksanakan dengan melakukan pendampingan yang dilakukan pengurus Komunitas Exs Preman Solo, dengan rincian kegiatan sebagai berikut: 
a. Pendampingan terhadap pengurus

Pada setiap pelaksanaan program yang dijalankan komunitas, penulis melakukan pendampingan yang masih pada tahap belajar. Pendampingan dilaksanakan untuk membantu pengurus dalam peningkatan kemampuan tahsin tahfidz. Diharapkan dengan pendampingan yang telah dilakukan penulis, pengurus mampu memperoleh efek dan pengaruh positif.

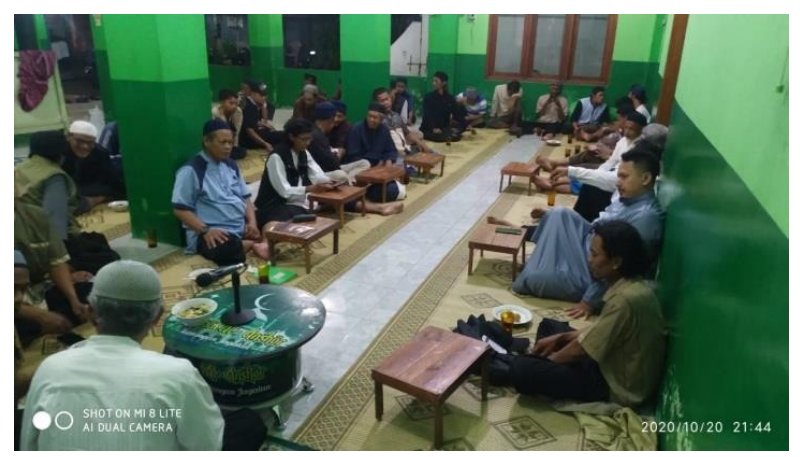

Gambar 1. Pelaksanaan pendampingan

b. Melakukan bimbingan dan pengarahan terhadap pengurus

Pelaksanaan pendampingan juga memerlukan bimbingan serta pengarahan dengan tujuan pengurus paham akan pendampingan peningkatan kemampuan yang dijalankan.

Bimbingan dilakukan dengan cara memberi pengetahuan serta pemahaman terhadap hal-hal yang perlu dilakukan saat pembinaan. Tujuan bimbingan yang dilakukan ialah pengembangan kemampuan pengurus agar pelaksaan pendampingan peningkatan kemampuan kedepannya dapat lebih baik dari sebelum-sebelumnya. Pendampingan dilakukan secara berkelanjutan untuk memberikan pemahaman terkait seperti apa sebaiknya pendampingan peningkatan kemampuan tahsin tahfidz dilakukan.

Pengarahan yang dilakukan terhadap pengurus dapat berupa strategi dan metode yang efektif dan inovatif dalam pelaksanaan pendampingan pelaksanaan kemampuan tahsin tafidz, melalui pengarahan tersebut mampu mencapai pendampingan yang diharapkan.

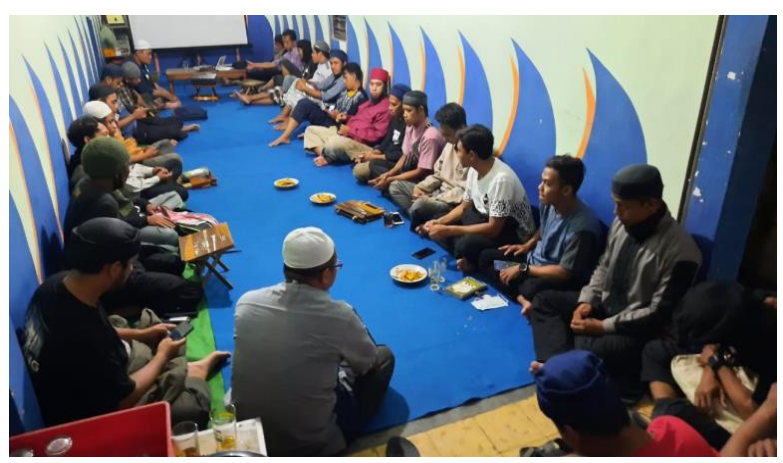

Gambar 2. Bimbingan Peningkatan Kemampuan

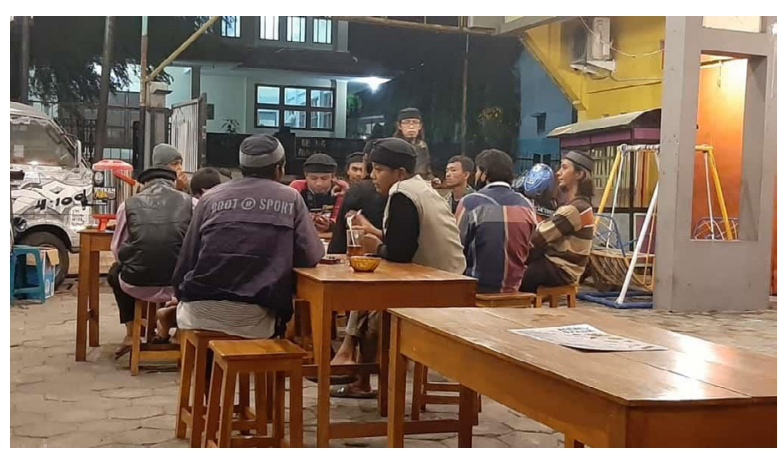

Gambar 3. Pengarahan Peningkatan Kemampuan

c. Memberi masukan serta saran

Memberikan masukan serta saran setelah berakhirnya pelaksanaan program yang dijalankan pengurus komunitas. Saran yang diberikan dapat berupa pembaharuan metode dan strategi pendampingan peningkatan kemampuan tahsin tahfidz. Permasalahan yang ditemui saat berlangsungnya program didiskusikan untuk kemudian dicari solusi yang tepat terhadap permasalahan yang ada tersebut, diharapkan dengan pemberian masukan serta saran mampu menjadikannya sebagai bahan evaluasi dan perbaikan dalam pelaksanaan program yang lebih baik lagi kedepannya. 


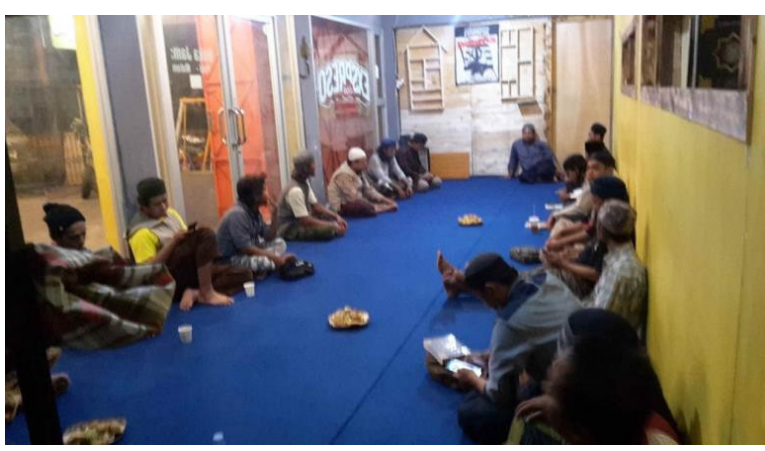

Gambar 4. Program Peningkatan Kemampuan

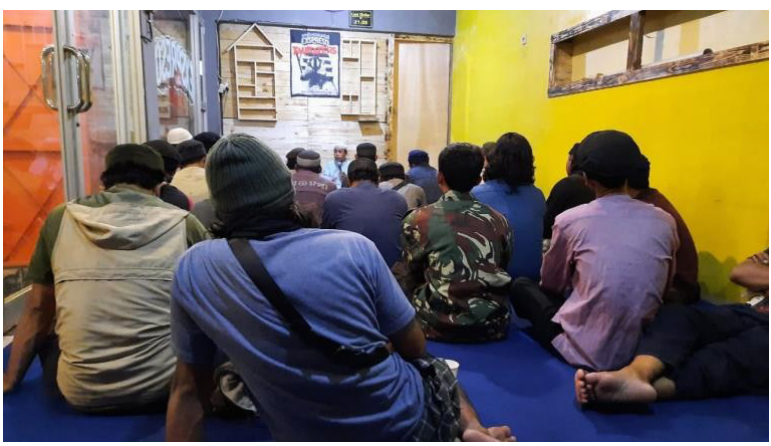

Gambar 5. Program Peningkatan Kemampuan

\section{Simpulan}

Pendampingan peningkatan kemampuan tahsin tahfidz di Komunitas Exs Preman Solo penting dilakukan pelaksanaannya, mengingat pendampingan ini mampu membantu para pengurus yang belum memiliki ilmu agama yang mumpuni untuk melakukan pembinaan terhadap anggota dalam peningkatan kemampuan tahsin tahfidz, untuk kemudian belajar bersama-sama agar tercapai yang diharapkan. Pendampingan yang dilakukan diharapkan mampu meningkatkan pengetahuan yang telah dimiliki para pengurus sebelumnya, sehingga dalam upaya peningkatan kemampuan tahsin tahfidz, para pengurus mampu membantu asatid dalam pelaksanaan programnya. Cara yang dilakukan dalam pendampingan ini ialah melakukan pendampingan, bimbingan, memberi masukan serta saran terhadap pengurus komunitas.

Pelaksanaan pendampingan ini memiliki tujuan agar para pengurus ma mpu membantu dalam upaya peningkatan kemampuan anggota komunitas, diharapkan pendampingan ini dapat dilakukan secara terus menerus bersama asatid.

\section{Persantunan}

Terlaksananya pengabdian masyarakat ini tidak terlepas dari bantuan berbagai pihak yaitu LPPM UMS, Prodi Pendidikan Agama Islam, Komunitas Exs Preman Solo dan Tim Pengapdian yang terdiri dari Nurul Latifatul Inayati, S.Pd.I., M.Pd.I, Diyah Purnamasari, Ahmad Imam Utomo.

\section{Referensi}

Referensi Buku:

Al Hafizh, Majdi. 2014. 9 Langkah Mudah Menghafal Al Qur'an. Solo:Aqwam. Ahmad Baduwailan, Menjadi Hafizh; Tips dan Motivasi Menghafal Al-Qur'an, terj. Cep Mochamad Faqih. Solo: PT. Aqwam Media Profetika.

Aziz Abdur Rauf, Abdul. 2010. Pedoman Dauroh Al Quran Kajian Ilmu Tajwid Disusun Secara Aplikatif. Jakarta: Markaz Al Qur'an.

Chusniatun, Nurul Latifatul, dan Maria Ulfa. 2018. Pendidikan Al Quran dan Pendidikan Hadist. Surakarta: Muhammadiyah University Press.

Joesoef, Soelaiman . 2004. Konsep Dasar Pendidikan Luar Sekolah. Jakarta: Bumi Aksara. Majid, Abdul. 2013. Setrategi Pembelajaran. Bandung: Remaja Rosdakarya .

Syaiful Anam, Ahmad dan Mu'minah, Amalia. 2013. Pengantar Ilmu Tahsin Kunci Mudah dan Praktis Membaca Al Qur'an. Surakarta: Yuma Pustaka 
Referensi Majalah:

Taufik. 2018. Ngopi dan Ngaji ala Ekspreso. Hadila Edisi 136 